DOI: https://doi.org/10.18485/philologia.2020.18.18.2

UDC: 811.111'282.4

\title{
QUESTIONING THE POSITION OF SBS AS THE MODEL VARIETY FOR SERBIAN EFL STUDENTS
}

\author{
NINA ĐUKIĆ ${ }^{1}$ \\ University of Belgrade \\ Faculty of Philology \\ Belgrade, Serbia
}

Rad prevashodno ispituje stavove srpskih studenata na 4. i 5. godini studija Anglistike prema standardnom varijetetu britanskog engleskog, kao i njegovu poziciju u odnosu na standardni američki i australijski engleski. Cilj ovog rada jeste da utvrdi da li standardni britanski engleski i dalje predstavlja primarni model za izgovor engleskog jezika kod studenata anglistike, kao i da istraži da li postoji hijerarhija među standardnim varijetetima engleskog. U radu je korišcen upitnik sastavljen kombinovanjem sociolingvističke tehnike za utvrđivanje stereotipa (eng. matched-guise technique), Likertove skale i pitanja otvorenog tipa. Pitanja su se odnosila na prepoznavanje akcenta, procenu karakternih osobina govornika podeljenih na kategorije društvenog statusa i dopadljivosti. Rezultati pokazuju da studenti pozitivno reaguju na američki i britanski akcenat. Međutim, ovaj rad daje i sledeće neočekivane rezultate: standardni britanski engleski ocenjen je ne samo kao najprestižniji, već i kao najdopadljiviji akcenat. Ovakav rezultat odstupa od dosadašnjih istraživanja i ukazuje na to da, iako je američki engleski prisutniji u govoru ispitanika, britanski engleski i dalje predstavlja primarni model kada se radi o izgovoru engleskog jezika.

Ključne reči: stavovi prema jeziku, standardni varijeteti engleskog, srpski studenti engleskog, američki engleski, britanski engleski, australijski engleski.

\section{INTRODUCTION}

Sociolinguistic research has found a clear parallel between a variety of English used in speech and the perception of the speaker using it (Giles 1970; Bayard et al. 2001; Ladegaard and Sachdev 2006). This perception includes both social status as well as assumptions regarding the personality of the speaker, i.e. social attractiveness.

1 Kontakt podaci (Email): djukic.nina96@gmail.com 
Naturally, this applies to both native and non-native speakers. However, non-native speakers are most commonly presented with a certain model of English in the classroom that they are required to emulate in order to learn the language in a manner that would enable them to understand and be understood clearly. In Serbia, traditionally, SBS has had the status of a target variety in L2 learning in Serbia for many decades (Čubrović and Bjelaković 2020: 140). Thus, the aim of this paper is to determine whether SBS still retains the same dominant position with Serbian EFL students in comparison with two other standard varieties of English: General American and Standard Australian English. Namely, this is to be attempted by using feedback from final-year university students at the Faculty of Philology, University of Belgrade, Serbia. In addition, this study seeks to determine whether a clear hierarchy or bias exists even in the scope of strictly standard native varieties. In this comparison SBS is presumed to rank as the "most standard", very likely followed by GA. The insights collected through this research study could serve as a sample illustrating the present attitudes of Serbian EFL students, i.e. could possibly single out SBS as the more dominant variety. In this case, the results might point to a need for greater exposure and familiarization with different varieties of English and enhancement of students' intercultural communication skills.

\section{PREVIOUS STUDIES}

Various attitudinal studies addressed and examined the opposition between standard and regional native English varieties and have shown that standard varieties of English are perceived as more prestigious and, simply, more correct (Giles 1970; Bayard et al. 2001; Coupland and Bishop 2007; Paunović 2009), SBS traditionally ranking the highest in this respect.

Rindal $(2010,2014)$ examines attitudes of adolescent Norwegian students towards the two model varieties of English present in their education system - American and British English. This study includes attitudinal research as well as the analysis of L2 speech of Norwegian adolescents in relation to their desired pronunciation. His results show that although SBS is singled out as the more prestigious variety, the one that is used more in practice is American English, being frequently associated with informality (Rindal 2010: 240). Thus, Rindal's research suggests that there is a discrepancy between the practical usage of English and the students' preferred variety. Namely, in previous instances of attitudinal research SBS was regularly found to be the preferred variety (Ladegaard 1998; Jarvella et al. 2001; Ladegaard and Sachdev 2006). Rindal's (2014: 331) results point out that both SBS and GA are seen as formally prestigious varieties that students also recognize as more standard compared to other varieties of English.

Ladegaard and Sachdev (2006: 91) yielded similar results with eighty-six Danish EFL students taking part in their research. Using a match-guised technique and dimensions of status, solidarity and attractiveness as dependent measures, the primary focus of this study was on attitudes towards SBS, GA, Cockney and Australian English. The following conclusions were given: "RP received favourable evaluation on all dimensions relating to status and competence. Furthermore, the quality of the RP speaker's language was 
regarded as superior on all dimensions compared to the other voices. Clearly RP was seen as the most prestigious accent of English" (Ladegaard and Sachdev 2006: 100).

On the other hand, Bayard (2001), who analyzed attitudes of EFL students from New Zealand, Australia and the US predicted that SBS would soon be surpassed by GA in terms of prestige. The varieties used in Bayard's research included SBS, GA, Australian and New Zealand variety. This study referenced older research that confirmed the traditional state of RP being the preferred English variety in terms of prestige, but less comprehensible to the participants (Stewart et al. 1985: 130). The fact that an American speaker ranked higher in terms of prestige and social attractiveness pointed to a possible shift in attitudes in Bayard's research, at least with native (Australian, New Zealand and American) speakers.

In terms of native English varieties, traditionally, SBS has had the status of the target variety in L2 learning in Serbia for many decades (Čubrović and Bjelaković 2020: 140). Additionally, Čubrović and Bjelaković (2020: 140) note that GA was only recently introduced in the syllabus of English phonetics at the University of Belgrade since "[t] raditionally, English Phonetics and pronunciation classes have been based on the description and transcription of SBS since the foundation of the English Department in Belgrade in 1929". What is more, they concluded that Serbian EFL students are far more exposed to General American, despite the fact that SBS often tends to be the accent of instruction in the classroom. Overall, their results imply that, while GA is more present in production, SBS still stands as the preferred model variety (Čubrović and Bjelaković 2020: 149), corresponding to Rindal's $(2010,2014)$ findings about Norwegian EFL students. These results suggest that a higher percentage of Serbian EFL students speak $\mathrm{GA}$, with a notably positive attitude towards SBS.

Paunović (2009) presented similar conclusions regarding Serbian EFL students, though this study included a larger number of both standard and regional varieties spoken by native speakers, even non-native varieties of English. When describing the offered varieties of English, Serbian EFL students exhibited tendencies similar to those of their peers. The attributes that students ascribed to the accents they heard generally fall under three categories: prestige, social and linguistic attractiveness (Paunovic 2009: 527). It was SBS and GA that scored highest in terms of prestige and desirability and somewhat lower in the dimension of social closeness. Out of the two, however, SBS was found to be the more desirable variety.

\section{METHODOLOGY}

A questionnaire was distributed to $4^{\text {th }}$ and $5^{\text {th }}$ year students (hereinafter "survey participants") of the English Department, Faculty of Philology in Belgrade, aged between 23 and 24, which yielded 36 responses. The questionnaire was administered online using Google Forms and required around 15 minutes to complete. It consisted of five sections and 51 questions in total, starting with the Section tackling personal questions, e.g. participant's age, what English accent they use etc. (Personal Section). The remaining 3 sections exposed the survey participants to a short recording, featuring 3 model speakers of standard varieties of English - Southern British Standard 
(SBS), General American (GA) and Australian (AusE)2. The audio files used in this questionnaire were taken from Collins and Mees (2013). All three model speakers were young adults and the topics in their recordings addressed either personal anecdotes or their studies - topics that were deemed appropriate for the average age of the survey participants.

InthePersonalSection, the respondentswereaskedabouttheirage, theaccentthey use, as well as the accent they would like to acquire and use. Regarding their own accent, answers were given in the form of a multiple-choice question, the options offered being "American", "British", "Australian" and an open short answer (labelled as "other"). The participants were offered the more general terms - American and British - rather than GA and SBS in order to avoid any possible ambiguity or confusion. The last two questions in the Personal Section, addressing the participants' accent in use and their preferred variety, were posed in order to compare the two and thus identify a possible existence of a personal preference or bias towards a particular accent. As regards accent identification, respondents were offered a short open answer instead of a multiple-choice question in order to elicit their own opinion on the accent they heard.

Sections 2 to 5 focused on the participants' assessment of the 3 speakers of native accents of English: GA, AusE, and SBS respectively. Each audio file was followed by an identical set of 12 questions, 6 of them addressing an attribute for each speaker in question. These traits may be divided into two groups: three of them involved the notions of prestige and correctness (educated, intelligent, reliable) and the other three referred to the speaker's personality (friendly, reserved, confident). In each question, participants were asked to assess how friendly, intelligent, reliable, educated, reserved and confident, respectively, a particular speaker was, using a Likert scale ranging from 1 to 5 . Number 1 signified "not at all", while 5 corresponded to "immensely". The respondents were given an additional question with a short open answer to describe the speakers further.

In the next question, the participants were required to identify the speaker's accent. They were also asked if they would like to speak that variety. The reason why variety identification was placed towards the end of each section was to avoid influence on the Likert scale assessment due to possible misidentification of the accent or, as Bayard explains it, in order not to "trigger the full suite of stereotypes associated with that dialect" (2001: 41). Once the participant consciously labelled the accent, they would be highly likely to ascribe a pre-existing attitude rather than respond spontaneously, based on what they hear while filling in this questionnaire.

A possible limitation of this research is that out of the 3 recorded speakers there were 2 female speakers (of GA and AusE), while SBS was represented by a male speaker. Additionally, each speaker had their own narrative, i.e., short monologues that were not similar in form or content. Thus, there was no uniformity of text or gender.

2 Initially, the research also included a model speaker of Canadian English. Since nearly none of the participants recognized this variety, it was excluded from the paper. 


\section{RESULTS AND DISCUSSION}

\subsection{ACCENT IN USE AND PREFERRED ACCENT}

Out of 36 participants, $86.1 \%$ stated that they use GA, while SBS constituted the remaining $13.9 \%$. No other variety was mentioned, though participants were offered GA, SBS, AusE and an open option to add any variety they found more appropriate to describe their own accent.

This ratio was foreseeable due to the notable influence of American English on Serbian EFL students and coincides with findings in other studies (Paunović 2009; Čubrović and Bjelaković 2020). Half of the respondents opted for GA as their preferred variety, making it the most desirable one. Furthermore, this implies that not all $86.1 \%$ of students who have a GA accent identified it as their desired one. This implies that, though not as present in everyday life, the Standard British variety still has a stable reputation with Serbian EFL speakers.

\section{Which accent would you like to have?}

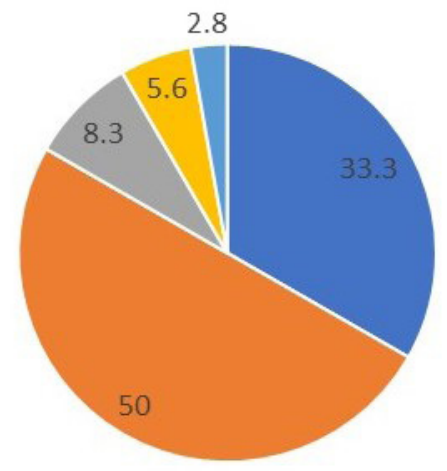

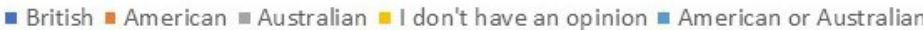

Figure 1. Participants' preferred variety

Additionally, three participants opted for Australian English as their preferred variety which, though not a large subset of the sample, still points to an interesting phenomenon that could be studied further. Bradley explains that Australian English is steadily gaining in popularity (2001:274), which he justifies with a notable proliferation of books, movies and series by Australian authors being released and being more available to the rest of the world. However, it is not clear to what degree Bradley's claim may apply to Serbia and its EFL speakers. If we assume that a larger amount of exposure to a certain variety is directly proportionate to its successful identification by EFL speakers, the results in the next section are likely to clarify the question of Serbian EFL speakers' exposure to AusE. 


\subsection{ACCENT IDENTIFICATION}

Participants were required to identify the variety at the very end of each section in order to avoid the conscious labelling of the variety. Though placed at the end, accent identification was a crucial form of verification. If the participants recognized the variety correctly, this would mean that all of their previous answers were valid, i.e. referred to the targeted variety and could be used for analysis. In addition, this section provides valuable insight regarding the participants' exposure to the three varieties analyzed in this study.

\subsubsection{SBS}

A successful rate of accent identification was anticipated from our participants since, together with GA, they were exposed to SBS the most, at least in the classroom context.

In terms of identification success, it can be concluded that participants had the least difficulty with SBS. Namely, $86.1 \%$ of participants successfully marked this variety as British, whereas only a small portion of them (11.1\%) misidentified it as another non-rhotic accent, e.g. Australian English. A possible reason for this may be the phonetic similarities between Australian English and SBS (Wells 1982: 595). Finally, only one participant marked this variety as GA, which makes SBS the most successfully identified variety of English in this research study.

\subsubsection{GA}

As many as 30 out of 36 participants (83.3\%) successfully identified this variety as $\mathrm{GA}$. Interestingly, the remaining number of participants who misidentified the variety offered non-rhotic varieties as their answers (AusE, SBS and "a mixture of AmE and BrE"). The GA model speaker exhibited all features of this rhotic variety, particularly rhoticity and t-voicing (Wells 1982: 248). A possible interpretation could be that this particular speaker's pronunciation and intonation may have misled the participants. Additional feedback on this model speaker will be provided in the answers to the openended questions (see Section 4.4).

\subsubsection{AUSTRALIAN ENGLISH}

Though AusE has prominent linguistic features, the amount of exposure to AusE is probably the prevalent factor in recognizing this variety. Out of all respondents, $52.7 \%$ of participants identified the accent correctly, while $25 \%$ opted for SBS. In addition, $8.3 \%$ believed that the speaker was from New Zealand, which, though not correct, was closer in geographical terms. The rest of the responses show either uncertainty (5.6\%) or the participants offering two options - Australian or British, Australian or South African (2.7\% each). What is interesting to note is that all of the answers offered by the participants include non-rhotic varieties exclusively, i.e. either AusE or its combination with a different non-rhotic variety. 


\subsection{ATTITUDES TOWARDS VARIETIES}

Next, the participants were offered six different adjectives that were considered relevant to assess the possible influence of the accent on their perception of the speaker's social status and personality traits: educated, intelligent, reliable, friendly, reserved, and confident. These particular adjectives were selected as a summary of adjectives used in the previous research (Bayard et al. 2001; Coupland and Bishop 2007; Paunović 2009; Rindal 2010, 2014).

Since all of the adjectives were assessed on a 1-to-5 Likert scale, Table 1 shows the average values each speaker received for each descriptor:

\begin{tabular}{|l|l|l|l|l|l|l|}
\hline & Friendly & Intelligent & Reliable & Educated & Reserved & Confident \\
\hline GA & 3.83 & 3.50 & 3.47 & 3.44 & 2.78 & 2.66 \\
\hline AusE & 3.28 & 3.50 & 3.58 & 3.72 & 2.91 & 3.28 \\
\hline SBS & 4.42 & 3.55 & 3.72 & 3.41 & 1.61 & 4.44 \\
\hline
\end{tabular}

Table 1. Mean values for all four varieties with each descriptor (all speakers)

As Paunović explains, "it is often pointed out that the varieties ranked high on social prestige tend to be rated rather low on social closeness and attractiveness, and vice versa" (2009: 535). According to the results in the research conducted by Paunović (2009), SBS indeed scored the highest with regard to prestige and vice versa. However, the results of this paper yielded some original results, which are presented next.

Table 1 shows that the SBS speaker was seen as the friendliest and least reserved, which contradicts the stereotypical image of an SBS speaker and implies that there has been a significant shift not solely in terms of accent, but also in the status and overall perception on the part of Serbian EFL speakers. The only result pertaining to the SBS speaker that matched the initial hypothesis was that he was seen as the most confident of the three. Interestingly, confidence was also one the most frequent qualities ascribed to this variety when the participants were asked why they would like to speak SBS (see Section 4.4). Overall, SBS was presumed to be dominant regarding social prestige, i.e. intelligence, education and reliability. Table 1 shows that the SBS Speaker ranks the highest on reliability and intelligence, but the score gap between SBS and the other two varieties is not as notable on intelligence and confidence. Intelligence, in particular has shown rather balanced results, which could imply that accent EFL students' perception of the speaker's intelligence.

Furthermore, an additional divergence from previous studies is certainly the Australian speaker who ranked as the least friendly-sounding and most reserved - a divergence from Paunović (2009) and Bayard et al. (2001), where Australian was ranked among the friendliest varieties. Conversely, in this study, the Australian speaker 
was deemed the most educated and had a moderately high score on reliability and intelligence. It appears that, in this research study, it is the AusE speaker who scored higher in terms of prestige and lower in social closeness - a result that was initially anticipated for the SBS speaker.

Additionally, what can be seen from Table 1 that falls out of line with previous research on this topic is the GA speaker ranking as the least friendly, the most reserved and by far the least confident. Namely, it was the SBS speaker that was the most likely to be labelled as reserved and, additionally, to score lower on the friendliness category.

\subsection{ATTITUDES TOWARDS VARIETIES: OPEN-ANSWER QUESTIONS}

The Likert scale questions were followed by open-answer questions asking the participants to describe the model speaker very briefly, in only a few words. This question aimed to elicit additional descriptors which may have been overlooked by the author and to allow the participants to express their attitudes more clearly. The answers offered by the participants mostly referred to the personality of the speaker, as well as their speech characteristics.

\subsubsection{SBS}

The results accrued for this speaker completely overlap with the Likert assessment and support the overwhelmingly positive feedback. SBS received a significantly larger number of positive descriptors in comparison to other varieties. These results further confirm that, in this research study, the SBS speaker was dominant regarding social attractiveness. Previous answers showed that SBS is still held in high regard by around one third of the survey participants (33.3\%) as the optimal standard variety for students to emulate and acquire. This percentage illustrates a steady decrease in "popularity" with the general EFL public. Thus, this part of the questionnaire may serve as additional evidence of a certain shift in view of SBS. In most instances of previous research (Paunović 2009; Rindal 2010, 2014), SBS ranked significantly higher in the domain of prestige, which was not the case in this questionnaire. Supplementary evidence may arise from the remaining questions that will be discussed in Section 4.5.

\subsubsection{GA SPEAKER}

For the GA speaker, the open answers provided further insight into the unexpectedly poor ranking in the previous section. The most common negative descriptors used included: hesitant, uncomfortable, insecure and reluctant - they mostly focus on the unnatural flow of speech, but not on any phonetic qualities, such as the speaker being unclear, difficult to understand or simply unpleasant. Quite the contrary, among the positive descriptors we can see that this speaker was perceived as pleasant by some participants. Nonetheless, the negative category remains dominant in this case. 
Likewise, in the Personality Section, the negative traits seem to slightly outweigh the positive ones, but the gap is certainly less notable. Namely, participants generally perceived this speaker as less assertive and open, which is probably connected to their claim that the speaker has difficulty expressing herself naturally and with ease. On the other hand, the positive claims stand in support of her calm character. Thus, it seems that both sides provide different perspectives on the same personality trait.

\subsubsection{AUSTRALIAN ENGLISH}

Each participant provided at least one adjective or phrase to further describe the Australian Speaker. The elicited descriptors added a somewhat contradictory aspect to the overall assessment of the Australian speaker since they were far more positive than the results in the previous section.

Though this was not as visible in the Likert assessment, the Australian speaker left a favourable impression, especially in terms of his character. The answers in this section are more in line with the initial hypothesis that the Australian speaker would be perceived as friendly. In fact, the Australian speaker was mostly described as laid back and rather approachable. However, several participants commented on the AusE speaker's speech, labelling it as unorganized and "scattered". In conclusion, the elicited descriptors together create a generally positive image of the AusE speaker.

When comparing the elicited descriptors with the ones offered by the author, a divergence is noted. The reason for this clear gap may lie in certain prosodic or paralinguistic features of this particular speaker, which prevented the formation of any clearer, more general assumptions on our part.

\subsection{ACCENT ATTITUDE}

This section will discuss the last question in the questionnaire which asked the participants whether they would like to use the accent they had just heard. The question offered three simple answers - "yes", "no" and "maybe". Additionally, our participants were required to elaborate on the short answer and include their justifications.

It is important to note that this question was asked after accent identification and Likert assessment questions, which means that the students most probably responded under the influence of the speaker as well as the accent they believed they had heard, not necessarily the actual accent they were listening to. Only the results for GA and SBS will be brought into focus since these two varieties were the only varieties our survey participants described as their own accents.

\subsubsection{SBS}

What follows are the results in total (Figure 2), as well as an additional illustration of how the students who speak SBS reacted to the model SBS speaker (Figure 3). 


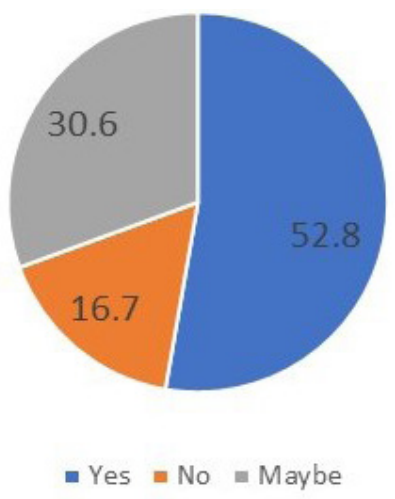

Figure 2. Participants' attitudes to speaking SBS

Slightly over a half of the participants stated that they would like to speak SBS. It can be concluded right away that in these $52.8 \%$, there must have been speakers of GA as well, which, as it had been stated before, indicates that SBS is still held in high regard. What follows is a separate figure that illustrates how only the SBS-speaking group responded to "Would you like to speak this accent (SBS)?".

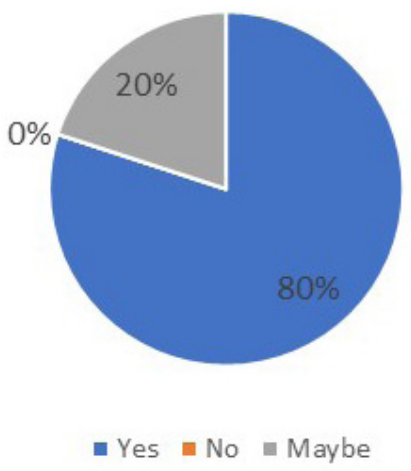

Figure 3. SBS-speaking participants' attitudes to speaking SBS

What can be concluded from Figure 3 is that all participants in the SBS-speaking group responded that they would like to speak this accent - $80 \%$ of them with certainty and the rest opted for "maybe". These results also overlap with the previous indications that the SBS model speaker left a positive impression in all respects.

Within the overwhelmingly positive feedback, most of the explanations may be classified as belonging to the domain of prestige. The most commonly used term to express this were "posh" and "sophisticated", which convey an attitude that coincides with the initial hypothesis and previous research (Paunović 2009; Rindal 2010, 2014). 


\subsubsection{GA}

As displayed in Figure 4 below, $27.8 \%$ of the total number of our participants said they would not like to speak with a GA accent. The remaining percentage opted for "yes" and "maybe", 38.9\% and 33.3\%, respectively. Upon comparing these results with the initial percentage of participants who reported that they spoke GA (86.1\%), it can be concluded that not all of our GA students reacted positively to the GA speaker they were listening to.

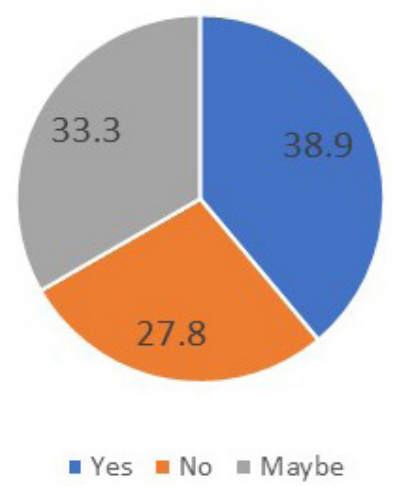

Figure 4. Participants' attitudes towards speaking in GA

In order to confirm what number of GA-speaking students opted against this accent, we consulted the individual questionnaires only of those students and summarized their responses in Figure 5 below.

The reason for a separate figure is to reach a clearer conclusion and determine whether the results are affected by non-GA speaking students or if the GA speaker's variety simply appeared less attractive to participants who, at least formally, share the same variety. The latter alternative is further made more likely if we take into consideration the participants' assessments in Section 4, which were overwhelmingly negative.

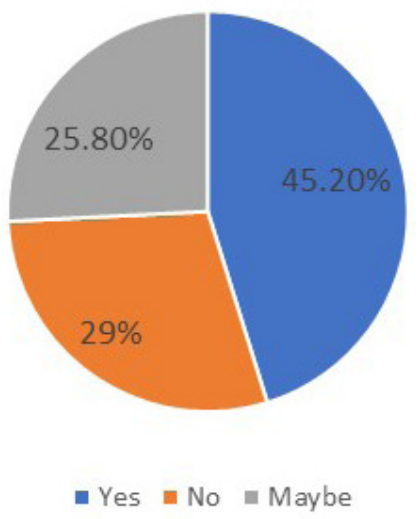

Figure 5. GA-speaking participants' attitudes towards speaking in GA 
The results show that close to half (45.2\%) of our GA participants approve of the accent they use. Interestingly, $29 \%$ of that same group opted against this variety, while $25.8 \%$ expressed uncertainty. These results may imply that, though GA is far more present in the speech of our participants, there might be a different variety deemed "more optimal" for speech, most likely SBS.

The reasons the survey participants offered to explain their answers in this section chiefly address the linguistic aspect associated with a particular variety of English. Most of the positive justifications focus on the comprehensibility of the accent. Furthermore, several participants also commented on the fact that GA is more present in everyday life, which confirms the initial hypothesis proven by the majority of GA speakers in this research study - many responses labelled this accent as "familiar" and "natural" and thus easier to acquire. Finally, several comments were more of an aesthetic nature, claiming that this accent simply "sounds nicer/prettier/more pleasant".

on the other hand, the negative feedback includes remarks on the accent's auditory quality, several participants stating that they minded the pronunciation of the vowels, words or the general lack of auditory appeal. Finally, though this speaker certainly is a native speaker of GA, some participants found the accent "forced" and "unnatural".

To summarize, though opinions were divided, the received positive feedback was anticipated since the large majority of our participants identified their accent as GA.

\subsubsection{AUSTRALIAN ENGLISH}

Initially, three participants stated that they would like to have an Australian accent. Later in the questionnaire, this variety was assessed in a somewhat balanced tone. Thus, the results in this section were expected to mirror the same ratio between the positive and negative ends of the spectrum.

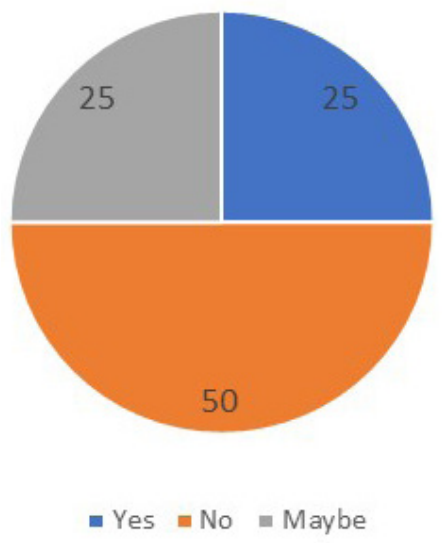

Figure 6. Participants' attitudes to speaking in AusE 
As seen in Figure 6, exactly one half of the participants said they would not like to speak Australian English, whereas the other half chose either "yes" or "maybe".

Similar to the explanations with the previous speaker, these too lean mostly towards the linguistic properties of the accent - many of them beginning with "it sounds" or directly commenting on the phonetic features (phoneme realization, vowel quality, etc.). The positive and negative explanations are fairly balanced in the case of Australian English. We can see from both positive and negative justifications that our participants found this accent to be unusual, somewhat detached and "nonstandard". However, while some participants found this appealing and fascinating, many complained about the clarity this accent purportedly lacks. In addition, we can see several comments that target specifically the pronunciation of vowels as one of the main reasons why the accent is unclear.

\section{CONCLUSION}

This paper yielded some unforeseen results regarding the position of SBS as a model variety with advanced Serbian EFL students. Firstly, on a more global level, the results confirm the existence of a hierarchy even within standard varieties of English. In particular, among the three standard varieties of English, SBS and GA seem to have been marked as "more standard". Secondly, it has been shown that, although GA is used far more frequently by EFL students, it is SBS that ranks as the more desirable one. These results partially overlap with previous research (Ladegaard and Sachdev 2006; Paunović 2009; Rindal 2010; Čubrović and Bjelaković 2020), as well as the initial hypothesis. Finally, as the focal point of the paper, SBS yielded the most surprising results. Initially, it was expected to be the most dominant in terms of social status, but ranked lower on the social attractiveness scale, following the already established pattern (Paunovic 2009). Nonetheless, in this paper, SBS ranked the highest for both prestige and social closeness. This finding does not fall in line with the above-mentioned studies, but it might imply that the desirability of SBS still extends to the aspects of social closeness, not solely social status.

In conclusion, these results imply that, although SBS is used less frequently by Serbian EFL students, it still retains its position as the key model variety. It is seen as more appealing, more prestigious, and also more socially attractive. Such an attitude may be ascribed to its rare occurrences in speech, which only contributed additionally to its prominently positive ranking - an assumption that leaves room for more detailed research on this topic. In addition, what remains to be ascertained with further investigation is the non-linguistic impact on the participants' assessments - that is to say, to which degree the participants assessed the speakers, instead of their accents.

One of the possible research directions is to further investigate the ranking of SBS by varying the context of use - how popular and comprehensible it is with students when used in various media (e.g. movies and series), as a variety of instruction (i.e. in the classroom and exams), in everyday conversation with native peers, etc. Additionally, more uniformity concerning the model speakers may provide more precision in assessments and direct the participants' attention solely to the accent in question. Such 
an approach could confirm whether the notable dominance that SBS has with Serbian EFL students applies to multiple contexts and is thus more beneficial for learning than other varieties of English.

\section{REFERENCES}

Bayard, D. et al. 2001. Pax Americana: Accent attitudinal evaluations in New Zealand, Australia, and America. Journal of Sociolinguistics 5(1), 22-49.

Bradley, D. \& M. Bradley. 2001. Changing attitudes to Australian English. In D. Blair and P. Collins (eds.) English in Australia. Amsterdam: John Benjamins, 271-285.

Collins, B. \& I. M. Mees. 2013. Practical Phonetics and Phonology. $3^{\text {rd }}$ Edition. London and New York: Routledge.

Coupland, N. \& H. Bishop. 2007. Ideologised values for British accents. Journal of Sociolinguistics 11(1), 74-93.

Čubrović, B. \& A. Bjelaković. 2020. Pronunciation Model Selection, or Do You Speak American?. In B. Čubrović (ed.) BELLS90 Proceedings: International Conference to Mark the $90^{\text {th }}$ Anniversary of the English Department, Faculty of Philology, University of Belgrade. Vol. 1. Belgrade: Faculty of Philology, University of Belgrade, 139-151.

Jarvella, R. et al. 2001. Of mouths and men: non-native listeners' identification and evaluation of varieties of English. International Journal of Applied Linguistics 11(1), 37-56.

Ladegaard, H. J. 1998. National stereotypes and language attitudes: The perception of British, American and Australian language and culture in Denmark. Language and Communication 18, 251-274.

Ladegaard, H. J. \& I. Sachdev. 2006. "I like the Americans... But I certainly don't aim for an American accent": Language attitudes, vitality and foreign language learning in Denmark. Journal of Multilingual and Multicultural Development 27(2), 91-108.

Melchers, G. \& P. Shaw. 2003. World Englishes. $1^{\text {st }}$ Edition. London: Arnold.

Paunović, T. 2009. Plus ça change. Poznań Studies in Contemporary Linguistics 45(4), 525-547.

Rindal, U. 2010. Constructing identity with L2: Pronunciation and attitudes among Norwegian learners of English. Journal of Sociolinguistics 14(2), 240-261.

Rindal, U. 2014. Questioning English standards: Learner attitudes and L2 choices in Norway. Multilingua 33(3-4), 313-334.

Rindal, U. \& C. Piercy. 2013. Being 'neutral'? English pronunciation among Norwegian learners. World Englishes 32(2), 211-229.

Seidlhofer, B. 2001. Closing a conceptual gap: The case for a description of English as a lingua franca. International Journal of Applied Linguistics 11(2), 133-158.

Seidlhofer, B. 2005. Understanding English as a Lingua Franca. Oxford: Oxford University Press.

Stewart, M. A. et al. 1985. Accent and social class effects on status and solidarity evaluations. Personality and Social Psychology Bulletin 11(1), 98-105.

Wells, J. C. 1982. Accents of English. Cambridge: Cambridge University Press. 


\section{SUMMARY}

\section{QUESTIONING THE POSITION OF SBS AS THE MODEL VARIETY FOR SERBIAN EFL STUDENTS}

This paper primarily investigates the attitude of Serbian EFL students, in their $4^{\text {th }}$ and $5^{\text {th }}$ year of university studies, towards the Southern British Standard variety of English, as well as its position in comparison with General American (GA) and Standard Australian English. The aim of this study is to determine whether SBS still remains the preferred model variety in Serbia, as well as to simultaneously investigate if a hierarchy also exists among standard varieties of English. The participants completed a questionnaire that combined the matched-guise technique with the Likert-scale and a series of open-ended questions. The questions cover the identification of one of the three varieties of English, assessment of model speakers' traits classified into social status and social closeness. Results show that, overall, EFL students react more positively to GA and SBS. However, this paper reports some unexpected results - SBS ranks the highest not only in terms of prestige, but also social closeness. This finding diverges from previous research and implies that, although GA might be more present in production with this group of EFL students, SBS still holds the position of the primary model variety, whose dominance also extends to social attractiveness.

KEYWORDS: language attitudes, standard English varieties, Serbian EFL speakers, GA, SBS, Australian English.

ARTICLE INFO:

Original research article Received: November 2, 2020

Revised: December 15, 2020

Accepted: December 20, 2020 